\title{
Síndrome hemorrágica associada à trombocitopenia idiopática em vaca Girolando
}

Rodrigo Melo Meneses;', Sara Engel, Douglas Rodrigues do Nascimento Gonzaga, Michelle Endrey Godoy, José Azael Zambrano Uribe, Ronaldo Alves Martins, Antônio Último de Carvalho, Elias Jorge Facury Filho

Departamento de Clínica e Cirurgia Veterinárias, Escola de Veterinária, Universidade Federal de Minas Gerais (UFMG), Belo Horizonte, MG, Brasil

*Autor correspondente

e-mail: menesesrm@gmail.com

\section{Resumo}

As doenças hemorrágicas abrangem diversas condições clínicas, sendo caracterizadas desde hemorragias subcutâneas a sangramento de mucosas de graus variáveis. Trombocitopenia é a causa mais comum de coagulopatias em bovinos leiteiros e pode ser resultado da redução da produção, aumento da destruição, sequestro ou consumo de plaquetas. Trombocitopenia idiopática é o termo utilizado para quadros imunomediados, já que raramente é possível a sua confirmação clinicopatológica em ruminantes. 0 presente trabalho relata um caso de uma síndrome hemorrágica associada a um quadro de trombocitopenia, em uma fêmea bovina, Girolando, de 6 anos de idade, atendida no Hospital Veterinário da UFMG, em junho de 2016. 0 animal pertencia ao lote de alta produção da fazenda (média de $22 \mathrm{~kg} /$ dia de leite) e estava em lactação havia 90 dias. A alimentação era à base de silagem de milho, além de pastagem de capim mombaça e braquiária, 6kg de ração e sal mineral ad libitum. De acordo com o proprietário, nove animais da propriedade apresentaram quadros similares no último ano e foram tratados com diaceturato de diminazeno, oxitetraciclina e polivitamínicos, porém não apresentaram melhora e morreram. 0 exame físico do animal revelou apatia, anorexia, mucosas hipocoradas, com presença de petéquias, temperatura retal de $38,8^{\circ} \mathrm{C}$, escore corporal 2 (escala 1-5), tempo de preenchimento capilar de 4 segundos, turgor de pele diminuído, epistaxe e sangramentos em regiões da pele picadas por carrapatos. 0 hemograma revelou anemia macrocítica normocrômica (hematócrito 14\%, hemácias 1,52 milhões/mm³ , VCM 92,11fl, HCM 27,83pg), leucocitose $\left(16.898 / \mathrm{mm}^{3}\right)$ caracterizada por neutrofilia $\left(10.138,8 / \mathrm{mm}^{3}\right)$ e discreta monocitose $(844,90 /$ $\mathrm{mm}^{3}$ ), além de trombocitopenia (30.000 plaquetas $/ \mathrm{mm}^{3}$ ). A bioquímica sérica mostrou hipoproteinemia (5,6 g/dL) por hipoalbuminemia $(1,81 \mathrm{~g} / \mathrm{dL})$. 0 tempo de protombina se apresentou normal $(24,6$ segundos $)$ e o de tromboplastina parcial ativada diminuído (18,7 segundos). 0 mielograma apresentou hiperplasia 
das linhagens eritróide e megacariocítica. Além disso, a pesquisa de ptaquilosídeo no leite e a PCR para o vírus da diarreia viral bovina foram negativos. Amostras de fezes e urina foram positivas no teste de sangue oculto. 0 tratamento consistiu em transfusão de sangue (5L), oxitetraciclina $(20 \mathrm{mg} / \mathrm{kg}$, intramuscular, a cada $48 \mathrm{~h}$, totalizando três aplicações), além de dexametasona (três aplicações a cada $24 \mathrm{~h}$, intramuscular, na dose de $0,05 \mathrm{mg} / \mathrm{kg}$ e duas aplicações na dose de $0,02 \mathrm{mg} / \mathrm{kg}$ ). Adicionalmente, realizou-se hidratação oral, 20 litros a cada $12 \mathrm{~h}$, até o restabelecimento hídrico do animal, que apresentou melhora significativa uma semana após o início do tratamento, recebendo alta 15 dias após a entrada no hospital. Portanto, diante dos achados clínicos e laboratoriais, assim como da resposta terapêutica, o quadro clínico foi compatível com trombocitopenia imunomediada, que pode estar relacionada ao aumento da destruição de plaquetas. Síndromes hemorrágicas imunomediadas em bovinos são pouco descritas, sendo os seus relatos importantes para reforçá-las como diagnóstico diferencial nos quadros de diáteses hemorrágicas. 